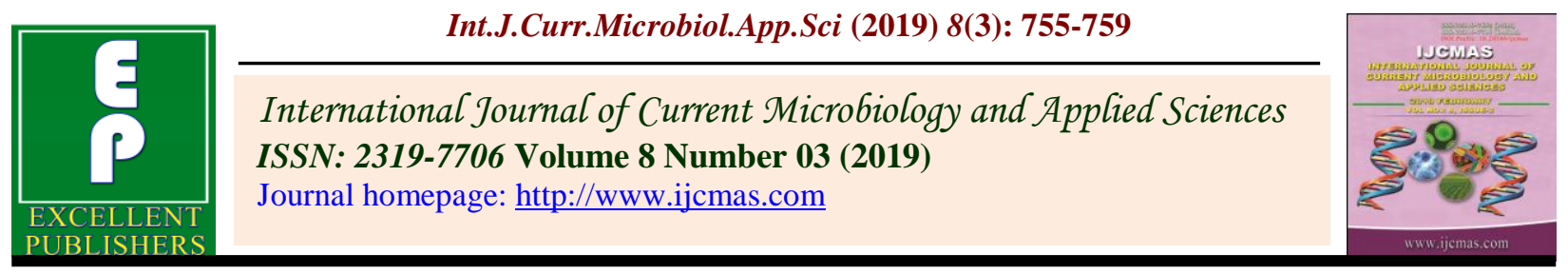

Original Research Article

https://doi.org/10.20546/ijcmas.2019.803.092

\title{
Effect of Spacing and Fertility Levels on Yield and Productivity of Multi-cut Forage Sorghum [Sorghum bicolor (L.) Moench]
}

\author{
Surja Ram, V. Nepalia, Ganga Ram Mali*, Manish Bera and Dileep Singh \\ Rajasthan College of Agriculture, Maharana Pratap University of Agriculture and \\ Technology, Udaipur - 313001 (Rajasthan), India
}

*Corresponding author

\begin{abstract}
A B S T R A C T
Keywords

Spacing and

Fertility Levels,

Sorghum

(Sorghum bicolor)

Article Info

Accepted:

07 February 2019

Available Online:

10 March 2019

A field experiment was conducted for Evaluation of Spacing and Fertility Levels for Multi-Cut Forage Sorghum. It was found that maximum increase in maximum increase in green and dry fodder yield was obtained with spacing $30 \mathrm{~cm}$ x $10 \mathrm{~cm}$ (54.77 and $15.91 \mathrm{t} /$ ha, respectively) with the highest net returns ( $₹ 44881 / \mathrm{ha}$ ) and B-C ratio (1.41) and application of $125 \%$ RDF proved most economically as it recorded highest net returns (₹46607 /ha) and B C ratio (1.42) compared to $75 \% \mathrm{RDF}$ and $100 \% \mathrm{RDF}$.

\section{Introduction}

India has very large population of livestock, the productivity of milk and other livestock product per animal is very low compared to other many countries in the world. One of the main reasons for the low productivity of our livestock is malnutrition, under-nutrition or both, beside the low genetic potential of the animals. The adequate supply of nutritive fodder and feed is a crucial factor impacting the productivity and performance of the animals. The country is highly deficient in respect of availability of green fodder, dry fodder and concentrates (Grover and Kumar, 2012). Feeding is the major component of

cost of milk production accounting for 55-60 per cent of the total cost of milk production. It is estimated that the world food requirement by the year 2050 will be double that of 2010 . A significant part of this requirement will emanate from the developing countries, on account of increased human populations, disposable incomes and urbanization. For livestock products, about two-thirds of this increased demand will need to be met by improving the production efficiency of feed, both forages and concentrate feeds. However, in addition to shortage of feed, it is well documented worldwide that imbalanced nutrition is a major factor responsible for low livestock productivity (Tonapi et al., 2011).
\end{abstract}


Globally, sorghum is cultivated on 41 million hectares to produce 64.20 million tonnes, with productivity hovering around 1.60 tonnes per hectare. With exceptions in some regions, it is mainly produced and consumed by poor farmers. India contributes about $16 \%$ of the world's sorghum production. It is the fifth most important cereal crop in the country. It is now recognized worldwide as a smart crop capable of providing food, feed, fodder and fuel especially under moderate inputs, especially in water-deficit environments in the low rainfall areas. It is grown as green forage (multi-cut) crop in north-Indian plains where irrigation is available and as single-cut forage mainly in drier parts of Western India (Tonapi et al., 2011). Sorghum plants contain an alkaloid, which releases hydrocyanic, or prussic acid, when hydrolyzed. This can be toxic to livestock. During periods of drought or other stresses, sorghum tends to accumulate nitrates, which can be toxic to livestock. If retarded crop growth is observed, forage needs to be analyzed for excessive nitrates before feeding (Pandey and Roy, 2011). Plant density is one of the important factor determines growth, development and yield. Plant density selection to allow for expression of maximum yield is a management practice that would make sorghum production more economical (Zand and Shakiba, 2013).

The plant population and plant spacing has always been complex question for sorghum (Wylie, 2008). Maintenance of optimum planting density through appropriate geometry is always a big problem to the farmers. Substandard plant density result in high weeds infestation, poor radiation use efficiency and low yield, while dense plant population on the other hand cause lodging, poor light penetration in the canopy, reduce photosynthesis production due to shading of lower leaves and drastically reduce the yield. Agronomic traits such as plant maturity, stalk strength and height were influenced little by varying row spacing (Schatz et al., 1990).

The agronomic traits like total tillers number, total fresh forage, total forage dry matter, leaf dry matter, stem dry matter and leaf-stem ratio are significantly affected by altering plant density of sorghum (Bahrani and Deghani ghenateghestani, 2004). Keeping the above facts in view, the present investigation was undertaken to know the effect of fertility and spacing on yield of forage sorghum.

\section{Materials and Methods}

A field experiment was conducted at Instructional Farm, Rajasthan College of Agriculture, MPUAT, Udaipur during Kharif, 2016 season with the objectives to select suitable multi-cut forage sorghum spacing for this zone, work out optimum fertility level for test sorghum genotypes and to access the economically viable treatment. Soil of the experimental field was sandy clay loam in texture and was medium in available nitrogen (281.40 kg /ha), phosphorus (21.46 kg /ha) and high in available potassium $(315.45 \mathrm{~kg}$ /ha). The experiment consisted of 27 treatment combinations comprising three levels of fertility (75, 100 and $125 \%$ RDF) and three spacing $(30 \mathrm{~cm} \times 10 \mathrm{~cm}, 30 \mathrm{~cm} \times 15$ $\mathrm{cm}$ and $45 \mathrm{~cm} \times 15 \mathrm{~cm}$ ) laid out in factorial randomized block design with three replications.

Yield attributes i.e., green forage, dry fodder yield and total fodder yield were recorded at $1^{\text {st }}$ and $2^{\text {nd }}$ time of harvest. THE economics analysis of each treatment was done on the basis of prevailing market rates of the inputs used and outputs obtained under each treatment. The crop was sown on 06 June 2016 and was harvested on 9 September and 20 October 2016 as $1^{\text {st }}$ and $2^{\text {nd }}$ cutting, respectively. 


\section{Results and Discussion}

\section{Effect of spacing}

\section{Green forage yield}

The maximum green forage yield of multicut forage sorghum at $1^{\text {st }}$ cutting was obtained by close spacing of $30 \mathrm{~cm} \mathrm{x} 10 \mathrm{~cm}(30.50$ t/ha). It was significantly superior (10.75 and 21.51 per cent) over wider spacing of $30 \mathrm{~cm} \mathrm{x}$ $15 \mathrm{~cm}$ and $45 \mathrm{~cm} \times 15 \mathrm{~cm}$, respectively. The data explicated that increasing spacing was associated with significant reduction of green forage yield at $2^{\text {nd }}$ cutting. The maximum yield (24.27 t/ha) was obtained when the crop was sown at closer spacing of $30 \mathrm{~cm} \times 10 \mathrm{~cm}$. It was reduced by 8.24 and 14.96 per cent by sowing the crop at wider spacing of $30 \mathrm{~cm} \mathrm{x}$ $15 \mathrm{~cm}$ and $45 \mathrm{~cm} \times 15 \mathrm{~cm}$, respectively. In tune with $1^{\text {st }}$ and $2^{\text {nd }}$ cutting data, the highest total green forage yield (54.77 t/ha) of the multi-cut forage sorghum crop was recorded under closer spacing of $30 \mathrm{~cm} \times 10 \mathrm{~cm}$ which was significantly higher (9.96 and 19.75 percent) over wider spacing of $30 \mathrm{~cm} \times 15 \mathrm{~cm}$ and $45 \mathrm{~cm} \times 15 \mathrm{~cm}$, respectively (Table 1).

\section{Dry fodder yield}

There was a gradual and significant reduction in dry fodder yield at $1^{\text {st }}$ cutting by increasing the spacing of crop. The maximum dry fodder yield $(7.71 \mathrm{t} / \mathrm{ha})$ was observed when the crop was closely spaced at $30 \mathrm{~cm}$ x $10 \mathrm{~cm}$. Widening the spacing to $30 \mathrm{~cm} \times 15 \mathrm{~cm}$ and $45 \mathrm{~cm} \times 15 \mathrm{~cm}$ was associated with significant reduction of 9.08 and 19.72 per cent in dry fodder yield, respectively in comparison to close spacing of $30 \mathrm{~cm} \mathrm{x} 10$ $\mathrm{cm}$. The maximum dry fodder yield at $2^{\text {nd }}$ cutting $(8.20 \mathrm{t} / \mathrm{ha})$ was recorded by keeping a spacing of $30 \mathrm{~cm} \times 10 \mathrm{~cm}$. It reduced significantly (7.56 and 13.78 per cent) by widening the spacing to $30 \mathrm{~cm} \times 15 \mathrm{~cm}$ and $45 \mathrm{~cm} \times 15 \mathrm{~cm}$, respectively. The maximum total dry fodder yield (15.91 t/ha) was obtained by closer spacing of $30 \mathrm{~cm} \times 10 \mathrm{~cm}$. It was significantly reduced by 8.30 and15.02 per cent by following wider spacing of $30 \mathrm{~cm}$ x $15 \mathrm{~cm}$ and $45 \mathrm{~cm} \mathrm{x} 15 \mathrm{~cm}$, respectively.

\section{Effect of fertility levels}

\section{Green forage yield}

An insight of data revealed that increasing fertility levels from $75 \%$ up to $125 \% \mathrm{RDF}$ tended to increase the green forage yield of the crop at $1^{\text {st }}$ cutting. Increase in level from 75 to $100 \%$ RDF and from 100 to $125 \%$ RDF gave 16.00 and 21.26 per cent forage yield enhancement. An examination of data revealed that fertility levels had significantly effect on green fodder yield at $2^{\text {nd }}$ cutting. The crop under the influence of $125 \%$ RDF produced the highest green forage yield at (23.87 t/ha $2^{\text {nd }}$ cutting, which was significantly higher over $75 \%$ and $100 \%$ RDF by 12.70 and 7.91 per cent, respectively. The total green forage yield was significantly influenced by fertility levels. The data revealed that the total green forage production was highest (56.66 t/ha) when soil was enriched with $125 \%$ RDF. It was significantly superior (15.26 and 27.35 per cent) over $100 \%$ and $75 \%$ RDF, respectively.

\section{Dry fodder yield}

The maximum dry fodder yield at first cutting (6.02 t/ha) was observed by supplying $75 \%$ $\mathrm{RDF}$ for crop raising. It was lifted to $6.90 \mathrm{t} / \mathrm{ha}$ by supplying $100 \% \mathrm{RDF}$ and to a maximum of 8.25 t/ha by supplying $125 \%$ RDF which was significantly higher over preceding levels. Though the minimum dry fodder yield (7.24 t/ha) was recorded by supplying $75 \%$ RDF but it was at par with yield obtained (7.53 t/ha) under $100 \%$ RDF. The minimum dry fodder yield $(8.08 \mathrm{t} / \mathrm{ha})$ was harvested by 
supplying $125 \%$ RDF which was for crop raising which was significantly significantly higher over 100 and $75 \%$ RDF. greater (13.17 and 23.15 per cent) over 100 The total dry fodder yield of multi-cut fodder sorghum increased significantly by supplying nutrients at an increasing rate over a range of 75 to $125 \%$ RDF. The maximum yield (16.33 t/ha) was observed by applying $125 \% \mathrm{RDF}$ and $75 \%$ RDF, respectively. The positive response of multi-cut sorghum crop to balanced fertilization is in close agreement with the findings of Singh et al., (2008), Singh et al., (2010) and Singh et al., (2014).

Table.1 Effect of spacing and fertility levels on yield of sorghum

\begin{tabular}{|c|c|c|c|c|c|c|}
\hline \multirow[t]{3}{*}{ Treatment } & \multicolumn{6}{|c|}{ Yield (t/ha) } \\
\hline & \multirow[b]{2}{*}{$\begin{array}{c}1^{\text {st }} \\
\text { Cutting }\end{array}$} & \multirow{2}{*}{ 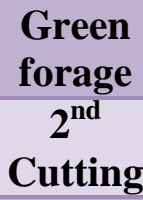 } & \multirow[b]{2}{*}{ Total } & \multicolumn{3}{|c|}{ Dry fodder } \\
\hline & & & & $\begin{array}{c}1^{\text {st }} \\
\text { Cutting }\end{array}$ & $\begin{array}{c}2^{\text {nd }} \\
\text { Cutting }\end{array}$ & Total \\
\hline \multicolumn{7}{|c|}{ Spacing $(\mathbf{c m} x$ cm) } \\
\hline $30 \times 10$ & 30.50 & 24.27 & 54.77 & 7.71 & 8.20 & 15.91 \\
\hline $30 \times 15$ & 27.54 & 22.27 & 49.81 & 7.01 & 7.58 & 14.59 \\
\hline $45 \times 15$ & 25.10 & 20.64 & 45.74 & 6.44 & 7.07 & 13.52 \\
\hline S Em \pm & 0.77 & 0.57 & 1.18 & 0.18 & 0.18 & 0.31 \\
\hline $\mathrm{CD}(\mathrm{P}=0.05)$ & 2.31 & 1.70 & 3.53 & 0.54 & 0.53 & 0.94 \\
\hline \multicolumn{7}{|l|}{ Fertility levels } \\
\hline 75\% RDF & 23.31 & 21.18 & 44.49 & 6.02 & 7.24 & 13.26 \\
\hline $100 \%$ RDF* $^{*}$ & 27.04 & 22.12 & 49.16 & 6.90 & 7.53 & 14.43 \\
\hline $125 \%$ RDF & 32.79 & 23.87 & 56.66 & 8.25 & 8.08 & 16.33 \\
\hline S Em \pm & 0.77 & 0.57 & 1.18 & 0.18 & 0.18 & 0.31 \\
\hline $\mathrm{CD}(\mathrm{P}=0.05)$ & 2.31 & 1.70 & 3.53 & 0.54 & 0.53 & 0.94 \\
\hline
\end{tabular}

* $90 \mathrm{~kg} \mathrm{~N}+40 \mathrm{~kg} \mathrm{P}_{2} \mathrm{O}_{5}+40 \mathrm{~kg} \mathrm{~K} 2 \mathrm{O} / \mathrm{ha}$

Table.2 Effect of spacing and fertility levels on net return and $\mathrm{BC}$ ratio of sorghum

\begin{tabular}{|l|c|c|}
\hline Treatments & Net return $(₹ /$ ha) & B C ratio \\
\hline Spacing $(\mathbf{c m} \mathbf{~ x ~ c m})$ & & \\
\hline $\mathbf{3 0} \times \mathbf{1 0}$ & 44881 & 1.41 \\
\hline $\mathbf{3 0} \times \mathbf{1 5}$ & 37941 & 1.19 \\
\hline $\mathbf{4 5} \times \mathbf{1 5}$ & 32541 & 1.03 \\
\hline $\mathbf{S ~ E m \pm}$ & 1650 & 0.05 \\
\hline $\mathbf{C D}(\mathbf{P}=\mathbf{0 . 0 5})$ & 4947 & 0.16 \\
\hline Fertility levels & & \\
\hline $\mathbf{7 5 \%}$ RDF & 31621 & 1.03 \\
\hline $\mathbf{1 0 0 \%}$ RDF & 37135 & 1.17 \\
\hline $\mathbf{1 2 5 \%}$ RDF & 46607 & 1.42 \\
\hline $\mathbf{S ~ E m \pm}$ & 1650 & 0.05 \\
\hline $\mathbf{C D}(\mathbf{P}=\mathbf{0 . 0 5})$ & 4947 & 0.16 \\
\hline
\end{tabular}

* $90 \mathrm{~kg} \mathrm{~N}+40 \mathrm{~kg} \mathrm{P}_{2} \mathrm{O}_{5}+40 \mathrm{~kg} \mathrm{~K}_{2} \mathrm{O} / \mathrm{ha}$ 


\section{Economics}

The data (Table 2) revealed that multi-cut sorghum spacing $30 \mathrm{~cm} \times 10 \mathrm{~cm}$ and $125 \%$ RDF fetched the highest net return and B C ratio of ₹ 44881 /ha, 1.41 and ₹ 46607 /ha, 1.42 respectively.

\section{References}

Bahrani, M.J., Deghani and Ghenateghestan, A. 2004. Summer forage sorghum yield, protein and prussic acid content as affected by plant density and nitrogen top dressing. Journal of Agricultural Science Technology. 6: 73-83-73.

Grover, D.K. and Kumar, S. 2012. AERC Study No. 29 Economics of production, processing and marketing of fodder crops in India (consolidated report). Agro-Economic Research centre Department of Economic and Sociology Punjab Agricultural University, Ludhiana-India.

Pandey, K.C. and Roy, A.K. 2011.Forage Crops Varieties. IGFRI Jhansi (India). pp. 1.

Schatz, B.G., Schneiter, A.A. and Gardner, J.E. 1990. Effect of plant density on grain sorghum production in North Dakota. North Dakota Farm Research. 47: 15-17.

Singh, H, Choudhary, M and Singh, P. 2010. Influence of fertility levels on fodder yield and $\mathrm{HCH}$ content in fodder sorghum [Sorghum bicolor (L.) Moench] varieties. Range Management and Agroforestry Issue (A):52-58.

Singh, P., Sumeriya, H.K. and Meena, A.K. 2014. Response of sorghum [Sorghum bicolor (L.) Moench] single cut forage genotypes to nitrogen levels. Annals of Agri-Bio Research. 19: 55-60.

Singh, P., Sumeriya, H.K., Sharma, V. and Chhipa, K.G. 2008. Study on effect of integrated nutrient management on promising sorghum genotypes SU1080. International Journal of Tropical Agriculture. 26: 409-411.

Tonapi, V.A., Patil, J.V., Rao, B.D., Elangovan, M.B., Bhat, V. and Raghavendra Rao, K.V. 2011. Sorghum: Vision 2030. Directorate of Sorghum Research, Rajendra Nagar, Hyderabad, Andhra Pradesh 500 030, India.

Wylie, P. 2008. Managing sorghum for high yields:A blueprint for doubling sorghum production. Grains Research and Development Corporation. Kingston ACT 2604.

Zand, N. and Shakiba, M.R. 2013. Effect of plant density and fertilizer on some attribute of grain sorghum [Sorghum bicolor (L.) Moench]. International Journal of Advanced Biological and Biomedical Research. 1: 1577-1582.

\section{How to cite this article:}

Surja Ram, V. Nepalia, Ganga Ram Mali, Manish Bera and Dileep Singh. 2019. Effect of Spacing and Fertility Levels on Yield and Productivity of Multi-cut Forage Sorghum [Sorghum bicolor (L.) Moench]". Int.J.Curr.Microbiol.App.Sci. 8(03): 755-759.

doi: https://doi.org/10.20546/ijcmas.2019.803.092 